\title{
Reflective Teaching and Professional Development of Young College English Teachers-From the Perspective of Constructivism
}

\author{
Jing Ma \\ Foreign Language Department, Qingdao University of Science and Technology, Qingdao 266001, China \\ Email: Majing508@163.com \\ Suzhen Ren \\ Qingdao University of Science and Technology, Qingdao 266001, China \\ Email: rensuzhen@hotmail.com
}

\begin{abstract}
In recent years, young college English teachers' professional development has become a core issue. The traditional training of young teachers ignored the empirical, experiencing and diversifying nature of language teachers' professional development. From the perspective of constructivism, this paper elaborates the impacts of teaching reflection on young college English teachers and highlights four effective methods and strategies to carry out reflective teaching.
\end{abstract}

Index Items—reflective teaching, teachers' professional development, constructivism, young English teachers

\section{INTRODUCTION}

Presently, young teachers account for the majority of college English teachers. The quality of young teachers is decisive for the overall quality of the college. Therefore, the demands on professional development of young college English teachers are becoming increasingly high. However, the in-service training and the traditional "top-down" model cannot satisfy the need of young college English teacher professional development. In the 1980s, a completely new model, "bottom-up" model, appeared in the teacher education field of such western countries as America and Britain, which has attracted many teacher education researchers into this field. This "bottom-up" model holds that a teacher should take the self as an important source in her/his professional development by reflecting upon her/his own teaching practice.

However, in the teacher education field of our country, such research is rare and just belongs to an initial stage. Based on the above reasons, it is significant for us to explore an effective way to young college English teacher professional development. The paper, guided by Piaget and Vyggosky's constructive theory, attempts to explore a constructive way for young college English teachers to promote their professional development.

\section{LITERATURE REVIEW}

\section{A. Constructivism}

Constructivism is a theory of how people learn, a philosophy that views learning as an active process in which learners construct their own understanding and knowledge of the world through action and reflection (Williams \& Burden, 2000). Constructivists argue that individuals generate rules and mental models as the result of their experiences with both other human subjects and their environments and in turn use these rules and models to make sense of new experiences (Henson \&Eller, 2005).

Constructivism focuses on learning process, which can be applied in teaching because teaching is learning and the process of teacher professional development is just a process of learning. So we can see the main underlying assumptions for reflective teaching and teaching professional development. Firstly, teacher professional development becomes possible only when teachers critically reflect upon teaching, for reflective teaching is the process of self-study or self-learning. Teachers are learning while teaching. Secondly, problem-solving provides an important means for reflective teaching. Teachers have to ask themselves questions to find ways to settle different problems met in the dynamic process of teaching because no methods or approaches can tell teachers the way to the most effective teaching. Teachers' feeling of success in problem-solving is a sign of professional development (Bailey et al, 2001).

B. Reflective Teaching 
Recently, a great deal of attention has been devoted to the topic of reflection and the development of reflective practice. More and more studies have been made to find out the nature of reflection and reflective practice.

Reflection has long been studied by many people. Dewey (1933) originally defined reflection as "active, persistent and careful consideration of any belief or supposed form of knowledge in the light of the grounds" (p.9). Bartlett (1990) also gives us his definition: reflection, or critical reflection, refers to an activity or process in which an experience is recalled, considered, and evaluated, usually in relation to a broader purpose. It is a response to past experience and involves conscious recall and examination of the experience as a basis for evaluation and decision-making, and as a source for planning and action.

Reflective teaching is a teaching theory that has drawn the attention of scholars in western countries and has influenced the educational system in China as well. Chinese foreign language educators and researchers introduced the trend of thought "reflective teaching" from abroad in the 1990s. From then on, researches on reflective teaching in China have started and flourished. Professor Xiong Chuanwu (1999) refines reflective teaching as "the process that the teacher as an active agent with the help of action research, keeps on inquiring and solving their own problems of the teaching goals and of teaching instruments, connects 'learning to teach' with 'learning to learn' and tries to improve rationality of teaching, and makes themselves a teacher of some scholar kind.(p.3)"

\section{SignificAnCE OF Reflective TEACHING ON PROFESSIONAL DEVELOPMENT}

Reflective teaching is seen as a process that can facilitate teaching, learning and understanding, and that plays a central role in teacher professional development. The significance of reflective teaching is well expounded by many scholars.

Dewey was among the first to promote reflection as a means of professional development in teaching. He believes that "critical reflection" is the most important quality a teacher may have and adds that "when teachers speculate, reason, and contemplate using open-mindedness, wholeheartedness, and responsibility, they will act with foresight and planning rather than basing their actions on tradition, authority, or impulse. Schon (1983) has demonstrated that reflection is an essential component of professional knowledge and practice and has believed that teachers will develop the ability for continued learning throughout the professional career if they are engaged in reflection in action. Richards and Lockhart (1996) argue that critical reflection of one's practices can trigger a deeper understanding of teaching and contribute to one's professional development. Wallace's (1991) reflective teaching model of professional education/development (Table 1) has clearly described the role of reflection in teacher professional development.

The significance of reflective teaching on professional development can be shown as follows. First, reflective teaching increases the degree of "professionalism". Teachers who are better informed as to the nature of their teaching are able to evaluate their stage of professional growth and what aspects of their teaching they need to change. Reflective practice offers practical options to address professional development issues. Secondly, it can help young teachers achieve a better understanding of their own assumptions about teaching as well as their own teaching practices; it can lead to a richer conceptualization of teaching and a better understanding of teaching and learning processes; it can serve as a basis of self-evaluation and is therefore an important component of professional development. Lastly, as young teachers gain experience in a community of professional educators, they feel the need to grow beyond the initial stages of survival in the classroom to reconstructing their own particular theory from their practice.

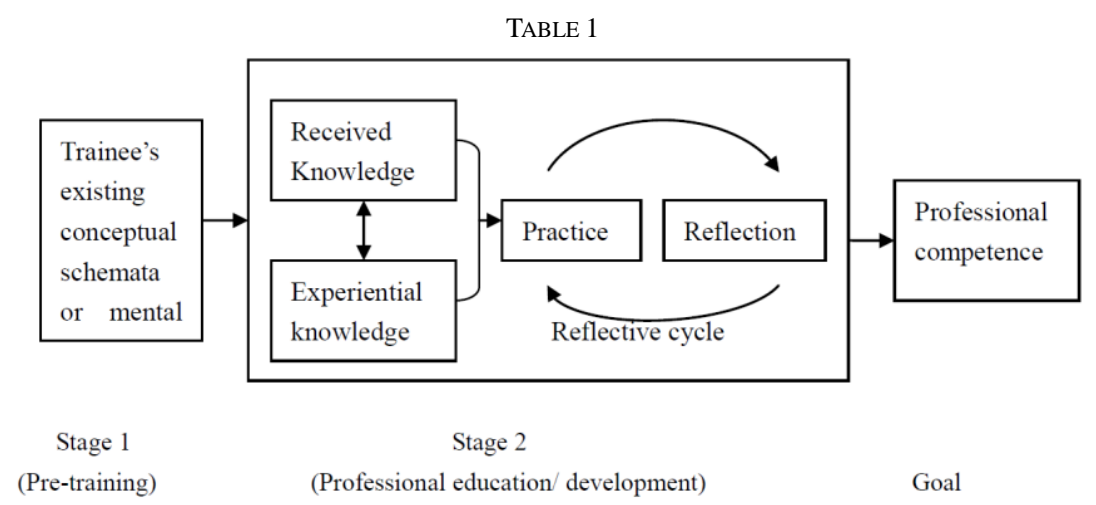

Reflective teaching has the effects of making teachers more initiative and responsible in pursuing the practical rationality through exploring teaching and learning activities, taking more informed actions and establishing a deeper understanding of teaching, which ultimately contributes to their professional knowledge and competence. So a process of reflective teaching is a process of teacher professional development. Without systematically reflective teaching, teacher professional development becomes impossible, and at the same time teacher professional development spurs teachers to do reflective thinking in their teaching.

\section{StRATEGIES OF REFLECTIVE TEACHING}


Based on the researches of reflective teaching both home and abroad as well as the author's own five years' teaching experience, four main strategies are suggested as follows.

\section{A. Observation}

Observation is the most basic research technique teachers can employ in classrooms. Teachers encounter many issues in classroom settings. Most of the rich data of classroom occurrences is gathered by the teacher himself/herself. Their peers also contribute. According to the author's investigation, $64 \%$ of the teachers occasionally ask their colleagues to observe their teaching and $15 \%$ of them can actively ask colleagues to observe their own teaching. It means that college English teachers also frequently use observation as a way to do reflection. Jack C. Richards and Charles Lockhart (1996) suggest observation as a way of gathering information about teaching, rather than a way of evaluating teaching.

In many language programs, young college English teachers are often reluctant to take part in observation or related activities since observation is associated with evaluation. Thus in order for observation to be viewed as a positive rather than a negative experience, the observer's function should be limited to that of gathering information. The observer should not be involved in evaluating a teacher's lesson.

Although observing the classes of young English teachers is a useful technique for them in order to gain valuable feedback on teaching and learning, observing another teacher's class can also be fruitful, especially observing the famous or experienced teachers' class.

Except for great knowledge of teaching theories, young college English teachers are lack of teaching practice. Therefore, observation is a good way for their professional development.

\section{B. Collaborative Learning}

It is often beneficial to gather feedback from academic colleagues. Brookfield (1995) maintains the importance of continual dialogue with peers and colleagues about teaching in the mutually cooperative environment rather than a competitive one. Collaboration with colleagues increases the probability that teachers will be successfully reflective and more confident in their professional development.

When discussing events young college English teachers have experienced, they can describe their own experiences and check, reframe and broaden their own theories of practice. Moreover, colleagues' diverse experiences, perspectives and ideologies can help young teachers avoid static, lopsided view. Plus, reciprocal peer discussion of pedagogical matters frequently with colleagues reveal that concerns or problems are shared, which not only validates a teacher's trials and successes, but also provides new perspectives and insights into problem — solving, enhance teaching skills.

\section{Teaching Blogs}

With the rapid development of information technology, more and more people choose blogs as the best way to express their feelings. The widest benefits of blogs will accrue to the young college English teachers. It is reported that only $14.4 \%$ teachers have never reflected upon their teaching by writing teaching blogs. That is, a large number of college English teachers use this method to record their teaching or their feeling about their teaching.

Teaching blogs are written or recorded accounts of teaching experiences, which will be about teachers' routine and conscious actions in the classroom. These actions include conversations with students, critical incidents in a lesson, teachers' beliefs about teaching, events outside the classroom that will influence teaching, and teachers' views about language teaching and learning. There are two purposes for teaching blogs, one of which is for later reflection and trigger teachers' insights about teaching by writing, and the other of which can involve all their students, their colleagues and other educators in the blogs so as to offer more advice on teaching.

\section{Audio and Video Recordings}

Through watching their own or other colleagues' audio and video recordings, young English teachers can develop their self-awareness for teaching is an independent and conscious activity of an individual.

A classroom video can vividly picture the whole process of teaching. It can trigger teachers' reflective thinking, reflect on their weaknesses and help them get some inspiration and ideas for their teaching improvement.

In doing reflective teaching, each strategy has advantages and limitations, and some are more useful for exploring certain aspects of teaching than others. It is up to initial teachers to decide which strategies are useful and for what purposes.

\section{CONCLUSION}

Due to the need of new curriculum and high demanding of college English teaching, professional development of young college English teachers in our country is extremely urgent.

From the perspective of constructivism, reflective teaching has proved to be an effective way to teacher professional development theoretically and practically, for reflective teaching can make a teacher become a life-long learner and researcher, can make a teacher become more self-aware and self-monitor of his own teaching, and cannot only change and but also integrated a teacher's teaching beliefs and practice.

\section{REFERENCES}


[1] Bailey, K. M., Curtis, A., \& Nunan, D. (2001). Pursuing Professional Development: The Self as Source. Boston, MA: Heinle \& Heinle.

[2] Bartlett. L (1990). Teacher development through reflective teaching. In J. C. Richards and D. Nuan(eds.). Second Language Teacher Education. New York: Cambridge University Press.

[3] Brookfield, S. (1995). Becoming a critically reflective teacher. San Francisco: Jossey-Bass.

[4] Dewev. J. (1933). How We think. Reprinted in W. B. Kolesnick (ed.). Mental Discipline in Modern Education. Madison: University of Wisconsin Press.

[5] Henson, \& Ellet, B. F. (2005). Educational Psychology for Effective Teaching. Beijing: Foreign Language Teaching and Research Press

[6] Piaget, J. (1974). To Understand is to Invent. New York: Viking Press.

[7] Richards, J. C. \& Lochkart, C. (1996). Reflective teaching in second Language classroom. Cambridge University Press.

[8] Schon, D. A. (1983). The reflective Practitioner: how professionals think in action. New York: Basic Books.

[9] Vygostsky, Lev S. (1978). Mind in Society. Cambridge, MA: Harvard University Press.

[10] Wallace, M. J. (1991). Training Foreign Language Teachers: A reflective approach. Cambridge: Cambridge University Press.

[11] Williams, Marion. \& Burden, Robert L. (2000). Psychology for Language Teachers. Cambridge, Cambridge University Press.

[12] Xiong Chuanwu, (1999). Reflective teaching. Shanghai: East China Normal University Press.

Jing Ma was born in Taian, Shandong Province, China in 1979. She received her M.A. degree in linguistics from Shanghai Jiaotong University, China in 2005.

She is currently a lecturer in the School of Foreign Language, Qingdao University of Science and Technology, Qingdao, China. Her research interests include language testing, translation and interpretation.

Suzhen Ren was born in Qingdao, China in 1960. She received her B.A. degree in English from Shandong Normal University, China in 1983.

She is currently a professor in Qingdao University of Science and Technology, Qingdao, China. Her research interests include Second Language Acquisition and Higher Education. 